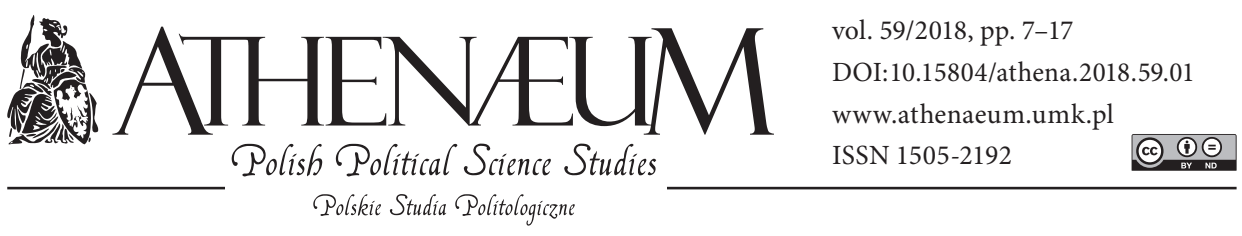

\title{
LIBERTARIANISM, FREEDOM AND THE PROBLEM OF CIRCULARITY
}

\author{
LIBERTARIANIZM, WOLNOŚĆ I PROBLEM BŁĘDNEGO KOŁA \\ Łukasz Dominiak*
}

\begin{abstract}
In the present paper the author considers a challenge to libertarianism posed by G.A. Cohen. The charge issued by Cohen says that libertarianism defines freedom in terms of justice and justice in terms of freedom. The paper deals with an aspect of this charge as expressed by one of Cohen's thought experiments according to which it is not the case that the answer to the question whether person $\mathrm{B}$ forces person $\mathrm{A}$ to do $\varphi$ depends on whether person B's actions are legitimate or not. Employing the Hohfeldian analysis of fundamental jural conceptions, the author demonstrates that if person B's actions are legitimate, then making person A to do $\varphi$ cannot, at pains of contradiction, be considered forcing. If person $\mathrm{B}$ is at a liberty to make person $\mathrm{A}$ to do $\varphi$, then person $\mathrm{B}$ cannot at the same time and in the same respect be at duty not to make person A to do $\varphi$. Yet, this is exactly what would follow if we adopted the stance that person B's legitimate actions force person $\mathrm{A}$ to do $\varphi$. If they forced person $\mathrm{A}$, then the expenditure of whatever labour needed to do $\varphi$ would not be a voluntary expenditure and
\end{abstract}

Niniejszy artykuł rozważa zarzut wobec libertarianizmu sformułowany przez G.A. Cohena. Zarzut ten mówi, że libertarianizm definiuje wolność w kategoriach sprawiedliwości, zaś sprawiedliwość w kategoriach wolności. Autor skupia się na szczególnym aspekcie tego zarzutu - wyrażonym w jednym $\mathrm{z}$ eksperymentów myślowych zaproponowanych przez Cohena - zgodnie z którym odpowiedź na pytanie o to, czy osoba B zmusza osobę A do zrobienia $\varphi$, nie zależy od tego, czy działania osoby B są prawowite, czy nie. Posługując się hohfeldowską analizą podstawowych pojęć jurydycznych, autor dowodzi, że jeżeli działania osoby B są prawowite, to skłonienie osoby A do podjęcia działania $\varphi$ nie może - za cenę popadnięcia w sprzeczność - być uznane za przymus. Jeżeli osoba B ma wolność jurydyczną skłonienia osoby A do podjęcia działania $\varphi$, to osoba B nie może jednocześnie i pod tym samym względem mieć obowiązku nieskłonienia osoby A do podjęcia działania $\varphi$. Jednak dokładnie taki wniosek wynikałby z przyjęcia stanowiska, że osoba B przez swoje prawowite działania mogłaby

* Nicolaus Copernicus University in Toruń, Faculty of Political Sciences and International Studies. ORCID: https://orcid.org/0000-0001-6192-8468. 
thereby would constitute a violation of person A's rights to this labour. However, if person A's rights were violated by person B's actions, then via Hohfeldian Correlativity Axiom person B would have to be at duty not to undertake these actions. Yet, the whole reasoning started from the assumption that person $\mathrm{B}$ is at liberty to undertake them.

Keywords: libertarianism, freedom, coercion, circularity, Hohfeld, G.A. Cohen zmusić osobę A do zrobienia $\varphi$. Jeśli działania te zmuszałyby osobę A do podjęcia działania $\varphi$, wówczas wydatkowanie jakiejkolwiek pracy związanej z robieniem $\varphi$ byłoby przypadkiem jej niedobrowolnego wydatkowania i konstytuowało tym samym naruszenie praw osoby A do owej pracy. Jeżeli natomiast prawa osoby A do jej pracy faktycznie zostałyby naruszone przez działania osoby B, to zgodnie $\mathrm{z}$ hohfeldowskim aksjomatem korelatywności na osobie B musiałby spoczywać obowiązek niepodejmowania tych działań. Całe powyższe rozumowanie opiera się jednak na założeniu, że osoba B ma wolność jurydyczną do ich podjęcia.

Słowa kluczowe: libertarianizm, wolność, przymus, błędne koło, Hohfeld, G.A. Cohen

\section{INTRODUCTION}

There is a circularity problem besetting the libertarian idea of freedom ${ }^{1}$. To the best of our knowledge this conundrum has been spotted for the first time by G.A. Cohen who pointed out that libertarianism defines freedom in terms of justice and justice in terms of freedom. As he noticed: “Thereby Nozick locks himself inside a circle. For Nozick, there is justice, which is to say no violation of anyone's rights, when there is lack of coercion, which means that there is justice when there is no restriction on freedom. But freedom is then itself defined in terms of non-violation of rights, and the result is a tight definitional circle and no purchase either on the concept of freedom or the concept of justice" (Cohen, 1995, p. 61). In the present paper we would like to focus only on a small aspect of this profound problem, an aspect which can yet appear very useful

${ }^{1}$ A precise definition of the libertarian idea of freedom has been provided by Rothbard who said that freedom is "a condition in which a person's ownership rights in his own body and his legitimate material property are not invaded, are not aggressed against” (Rothbard, 2006, p. 50). As one can readily see, on this account freedom is defined in terms of justice, i.e., in terms of property rights. On the other hand, justice is invaded when "the aggressor imposes his will over the natural property of another - he deprives the other man of his freedom" (Rothbard, 1998, p. 45). Hence, what is just and unjust is in turn determined by what does and what does not deprive the other man of his freedom. 
in attenuating the Cohen's challenge. The aspect we have in mind involves the question of conditions under which an exchange of goods and services is a free exchange. When person A chooses to provide a service or a good to person $\mathrm{B}$, the choice made by person $\mathrm{A}$ results in a valid property title transfer if and only if it is a free or voluntary choice. Obviously, a given choice is not free or voluntary when the chooser is forced or coerced by some other person to make it. But when is he forced or coerced? According to libertarianism, person B forces or coerces person A to make a choice if and only if actions undertaken by person B violate person A's property rights². As Nozick points out: "Whether a person's actions are voluntary depends on what it is that limits his alternatives. If facts of nature do so, the actions are voluntary. Other people's actions place limits on one's available opportunities. Whether this makes one's resulting action non-voluntary depends upon whether these others had the right to act as they did" (Nozick, 2014, p. 262). This of course makes an impression of circularity. A transfer of goods or services from person A to person B constitutes a violation of person A's property rights when the transfer is unfree. The transfer is in turn unfree when it involves property rights violation. It seems that it would be better if libertarianism had independent account of freedom or voluntariness so as to explain valid property rights transfers in terms of freedom or voluntariness but not the other way around. Then, for instance, a transfer from person A to person $\mathrm{B}$ would constitute violation of person A's property rights if it were unfree and

2 Richard A. Epstein writes: "Suppose that B has agreed to clean A's clothes for \$10. After the work is done, B tells A that he will return the clothes only if A pays, or promises to pay, him $\$ 15$. If A pays the $\$ 15$, it is quite clear that he has an action to recover the $\$ 5$ excess. $B$ has put him to a choice between his clothes and his money. As in the case of duress by the threat of force, B has required A to abandon one of his rights to protect another, and the action to recover the $\$ 5$ is designed to make certain that A will be able to protect them both.... Suppose that B at the outset refuses to clean A's clothes unless A pays him $\$ 15$, even when B's previous price had been $\$ 10$. There is no doubt that A is worse off on account of B's decision to make a 'take it or leave it' offer, but it would be the gravest mistake to argue that B's conduct constitutes actionable duress because it puts A to an uncomfortable choice. In- deed the case is sharply distinguishable both from the threats or use of force and from the duress of goods. In those two cases of duress, B put A to the choice between two of his entitlements. In this situation he only puts A to the choice between entitlement and desire, between A's money, which he owns, and B's services, which he desires. It is the very kind of choice involved in all exchanges. A could not complain if B decided not to make him any offer at all; why then is he entitled to complain if $\mathrm{B}$ decides to make him better off by now giving him a choice when before he had none? If A does not like B's offer, he can reject it; but to allow him to first accept the agreement and only thereafter to force B to work at a price which B finds unacceptable is to allow him to resort (with the aid of the state) to the very form of duress that on any theory is prohibited" (1975, p. 296, 297). 
it would be unfree if person B made all other options unappealing for person A, regardless of whether person $\mathrm{B}$ had a right to make them unappealing or not. In the present paper we will try to demonstrate that even though the libertarian account of freedom might suffer from circularity, the alternative, descriptive account suggested by Cohen seems to suffer from contradiction ${ }^{3}$. To show that it is indeed the case, we will employ the Hohfeldian matrix of jural relations to analyse one of the crucial thought experiments supporting the Cohen's challenge.

\section{HOHFELDIAN MATRIX OF JURAL RELATIONS}

To make sense of the argument that we are about to present, it seems helpful to remind ourselves of the analysis of fundamental jural conceptions proposed by Wesley N. Hohfeld $(1913,1917)$. Hohfeld noticed that the word 'right' appears in the legal discourse in an ambiguous way that causes interpretative problems, equivocations and other logical blunders. As he pointed out, all senses in which the word 'right' is used can and should be - in order to achieve logical consistency within the rights-talk - analysed into four distinct conceptions: claim-rights, liberty-rights, power-rights, and immunity-rights. Each of these conceptions has a different meaning that can be expressed in a precise logical form. For our purposes it is enough if we articulate meanings of only claim-rights and liberty-rights.

(1) Person A has a claim-right against person B that person B do $\varphi$ if and only if person $\mathrm{B}$ has a duty to person A to do $\varphi$. Respectively, person A has a claimright against person $\mathrm{B}$ that person $\mathrm{B}$ do not $\operatorname{do} \varphi$ if and only if person $\mathrm{B}$ has a duty to person A not to do $\varphi$.

(2) Person A has a liberty-right against person B to do $\varphi$ if and only if person B has a no-claim on person A that person A do not do $\varphi$. Respectively, person A has a liberty-right against person $\mathrm{B}$ not to do $\varphi$ if and only if person $\mathrm{B}$ has a no-claim on person $\mathrm{A}$ that person $\mathrm{A}$ do $\varphi$.

3 To the best of our knowledge, it was Alan Wertheimer (1989, pp. 251-255) who pointed out for the first time that Cohen's challenge can be overcome by paying attention to a normative aspect of coercion. Drawing on Wertheimer's original contribution, we would like to explain, by employing Hohfeldian analysis, why ignoring this normative aspect makes Cohen's account flawed and why libertarianism, with its thesis that all rights are property rights (Steiner, 1994, p. 94; Rothbard, 1998, p. 113), should not be bothered too much by the Cohen's challenge. 
It is readily visible that if person $B$ has a no-claim on person $A$, then person A does not have a duty to person $B$, since person $A$ can have a duty to person $B$ if and only if person $B$ has a claim-right against person $A$ (which is the opposite of no-claim). Thus, we can also notice another crucial aspect of the meaning of liberty-right:

(3) Person A has a liberty-right against person B to do $\varphi$ if and only if person A does not have a duty to person B not to do $\varphi$. Respectively, person A has a liberty-right against person $\mathrm{B}$ not to do $\varphi$ if and only if person A does not have a duty to person B to do $\varphi$.

We can therefore conclude that to have a liberty to do $\varphi$ is to have no duty not to do $\varphi$; to have a liberty not to do $\varphi$ is to have no duty to do $\varphi$; to have a duty to do $\varphi$ is to have no liberty not to do $\varphi$; and to have a duty not to do $\varphi$ is to have no liberty to do $\varphi$. It goes without saying that analogous relations hold between claim-rights and no-claims.

The aforementioned jural positions and their logical interconnections can also be presented in a form of matrix where jural correlates signify logical equivalences (as seen from two different points of view) while jural opposites logical contradictions (as seen from the same point of view). Our partial (without second order power-rights and immunity-rights) matrix can then look as follows (Hohfeld, 1913, p. 30, passim, 1917, p. 710, passim):

\begin{tabular}{|l|c|c|c|}
\hline \multirow{2}{*}{ Jural correlates } & Person A & claim & liberty \\
\cline { 2 - 4 } & Person B & duty & no-claim \\
\hline
\end{tabular}

\begin{tabular}{|c|c|c|c|c|}
\hline \multirow{2}{*}{ Jural opposites } & Person A & claim & liberty to & liberty not to \\
\cline { 2 - 5 } & Person A & no-claim & duty not to & duty to \\
\hline
\end{tabular}

It is important to note that any complex subjective rights can be analysed into Hohfeldian jural positions (Kramer, 2000, pp. 22-60). In the case of ownership rights, which in the present paper interest us the most, all aspects of this complex right can be reduced to fundamental deontic positions: (1) ius possidendi to Hohfeldian claim-rights and liberties to possess the resource in question; (2) ius utendi, ius fruendi and ius abutendi to liberties to use, to derive income, to destroy or waste the resource; (3) ius disponendi to Hohfeldian powers of disposition, 
management and transmissibility of the resource (see: Epstein, 1985, p. 59; Honoré, 1961, pp. 372-375). Additionally, Hohfeldian immunities against expropriation and termination of title can easily express other incidents of property rights, particularly as construed by the theory of Full Liberal Ownership. Thus, being equipped with such precise analytical weaponry, we are ready to examine the challenge to the libertarian idea of freedom posed by Cohen.

\section{FREEDOM AND PROPERTY RIGHTS}

To substantiate his point that libertarianism runs into circularity and relies on a counterintuitive account of freedom, Cohen suggests considering the following thought experiment. "Suppose farmer Fred owns a tract of land across which villager Victor has a right of way. Then, if Fred erects an insurmountable fence around the land, Victor is forced to use another route, as Nozick will agree, since Fred, in erecting the fence, acted illegitimately. Now consider farmer Giles, whose similar tract is regularly traversed by villager William, not as of right, but because Giles is a tolerant soul. But then Giles erects an insurmountable fence around his land for reasons which justify him in doing so. According to Nozick, William may not truly say that, like Victor, he is now forced to use another route. But the examples, though different, do not so contrast as to make such a statement false. William is no less forced to change his route than Victor is" (Cohen, 1995, p. 36).

What would the conclusion that William is also forced to change his route boil down to? First of all, as stated by the thought experiment, Giles is the owner of the tract of land. It follows then that Giles has, amongst other jural positions, a claim-right in rem that other people, William included, do not traverse his land without his consent. It also follows that Giles has a vested liberty to erect an insurmountable fence around his land for a just reason - as actually admitted by Cohen - reason to enforce the aforementioned claim-right included. This claim-right and liberty entail in turn on the part of other people, respectively, a duty not to traverse Giles' land without his consent and no-right that Giles forebear erecting the fence. What is more, Giles' rights to the tract of land are not whatever rights but property rights. It means that entitlements enjoyed by Giles are protected by property rules, not by liability rules (Calabresi \& Melamed, 1972, pp. 1089-1128; Epstein, 1997, p. 2091; Barnett, 2004, p. 186). Having said that, it is crucial to note that as a part of his property rights Giles has a liberty to erect the fence and William has a correlative no-claim that Giles do not erect the fence. 
As stated in the thought experiment, by erecting the fence, Giles makes ${ }^{4}$ William to take another route (supposedly, other options, such as not going anywhere, are still less appealing to William). If making William to take another route constituted forcing him to do so, then William's choice to take another route would not be a free choice and his expenditure of physical effort to take another route would not be a voluntary expenditure. The exchange of his labour for getting where he needs to get would then not be a free exchange. Since making someone to perform an involuntary action is under libertarianism considered violation of his rights, Giles would violate William's rights if he made him to take another route. It follows then that Giles would be at duty not to make William to take another route.

Thus, if making William to take another route constituted forcing him, then Giles would have a duty not to do that. Yet, as the thought experiment assumed, Giles is at liberty to erect the fence and erecting it makes William to take another route. It would then be the case that Giles would have a liberty to erect the fence and a duty not to make William to take another route. The ensuing problem is readily visible. If erecting the fence entails making William to take another route, then not making William to take another route entails not erecting the fence. If Giles had a duty not to make William to take another route, then he would also have a duty not to erect the fence. However, the thought experiment assumed that Giles has a liberty to erect the fence, i.e., no duty not to erect the fence. The conclusion that Giles has a duty not to erect the fence contradicts the assumption. Therefore, once Cohen assumes that Giles is the owner of the land and has a liberty to erect the fence, he cannot at the same time claim without running into contradiction that if Giles makes William to take another route by erecting the fence, he thereby forces William to do so. For if Giles were forcing William, he would be violating his rights, what would in turn mean that Giles had no liberty to erect the fence in the first place.

At the same time there is no contradiction in the case of Fred and Victor. Remember that Victor has an easement over Fred's land, i.e., he has a vested liberty to traverse Fred's land and this liberty is protected by Victor's right against

\footnotetext{
4 'Makes' does not necessarily mean 'forces'. Whether it does is to be settled in the course of the present paper. By 'makes' it is rather understood that Giles renders other options, particularly traversing the land, impossible or unappealing to William. Now the bone of contention is what kind of making other options unappealing constitutes forcing. According to such libertarians as Nozick or Rothbard, it is only illegitimate making that constitutes coercion whereas according to Cohen, making does not have to be illegitimate to constitute coercion.
} 
Fred and other innumerable people that he ought not to be prevented from crossing the tract. This in turn correlatively entails Fred's duty not to prevent Victor from traversing the land. Now if Fred erects the fence, he prevents Victor from crossing the land and thereby violates Victor's right. No contradiction ensues. What is more, one can also correctly conclude that since by erecting the fence Fred makes Victor to take another route, he forces the latter to expend his physical effort involuntarily and thereby violates his rights not to be forced to exchange his labour without consent. Again, there is nothing contradictory about such a conclusion. It is derivable from the assumption that Fred has a duty not to erect the fence. If erecting the fence entails making Victor to take another route and Fred has a duty not to erect the fence, then Fred has a duty not to make Victor to take another route (see: von Wright, 1951, p. 5).

To make our point clearer, consider another example ${ }^{5}$, this time less libertarian in its spirit, since not drawing on the thesis that all rights are property rights

5 The present example draws on Wertheimer's original modification of Cohen's thought experiment. Wertheimer's argument unfolds as follows: "But is it so obvious that W[illiam] is forced to change his route? Yes and no. Yes, it is obvious that there is a descriptive sense in which both V[ictor] and $\mathrm{W}$ are equally forced to use another route. In what sense, then, can we say that $\mathrm{W}$ is not forced to use another route? Consider my extension of Cohen's story. F proposes to sell $V$ a key to a gate that will allow $V$ to traverse F's tract. Because the value of traversing the tract exceeds the cost of the key, $V$ buys the key from F. G makes an identical proposal to $W$, who buys his key from $G$. Suppose that V and $\mathrm{W}$ now claim that they made their payments under duress, because, as Cohen says, F's and G's actions forced them to choose between making payments and what they regard as an unacceptable alternative, that is, not being able to traverse the tracts of land. I assume that whereas $\mathrm{V}$ can recover his payment, even Cohen would grant that W cannot. How could Cohen reach that conclusion? He could say that $\mathrm{W}$ cannot recover even though he was forced to pay. But, at least with respect to the sense of 'force' that has the relevant moral implications, we are, in fact, more inclined to say that $\mathrm{W}$ voluntarily paid for the right of way (whereas V did not). But I do not want to quibble about words. The point is that whatever locutions we want to use here, there is an important distinction between the bindingness of W's agreement and that of V's agreement. What is going on here? Why should Nozick want to deny that there is a sense in which $\mathrm{W}$ is forced to go around the tract of land or pay for the right of way? And why should Cohen want to deny that there is another sense in which $\mathrm{W}$ is not forced to pay? I am inclined to think that their errors can be traced to a common difficulty. Both Nozick and Cohen assume... Different versions of the 'right answer' thesis. Nozick can be read as arguing that the moralized account of coercion exhaust the field, and that there is no important sense in which $\mathrm{W}$ is forced to go around the fence. Although, as Cohen observes, that is obviously false, a moralized theory of coercion need hardly deny that such justified 'forcing' have the effect of constraining actions or behavior. On the other hand, Cohen is wrong to assume that a nonmoral account of coercion (or forcing) can do the requisite moral work. Cohen can treat all forcings as coercive if he prefers, but then he will need another principle to distinguish the coercion or forcing that invalidates agreements from coercion or forcing that does not. And, I suggest, even Cohen would need a moralized theory to make that sort of distinction" (1989, pp. 252-253). 
or that we own our labour. Imagine that person A owns a tract of land that is customarily traversed by person B. Then person A erects the insurmountable fence around the land and demands payment for traversing it (supposedly, person A installs the gates in the fence so as to let paying customers traverse his land). Imagine further that taking another route is highly unappealing for person $\mathrm{B}$, comparably unappealing as not going anywhere was in the original thought experiment (and still is). Person B is therefore made by person A to pay for traversing the land. Is making person $B$ to pay for traversing the land forcing them? It seems that Cohen would be committed to conclude that person $B$ is now forced by person A to pay for traversing the land. If that were the case, then we would also have to conclude that transfer of money from person B to person A was involuntary and therefore did not result in the successful transfer of property titles; it was rather a money-or-your-life kind of transfer. Yet certainly the right to the income (Honoré, 1961, p. 372) belongs to a person's ownership rights. Once we assume that person A is the owner of the tract, we willy-nilly assume that person A has a liberty to derive income from their property, e.g., by charging people who would like to traverse the land. This of course precludes us, at pains of contradiction, from concluding that person A who is the owner of the tract of land forces person B to pay for traversing it, since such a conclusion would entail that the transfer of person B's money is coerced, involuntary, unfree and so illegitimate, that it constitutes violation of person B's property rights and that in actual fact person A has always been at duty towards person B not to charge her for traversing the land. Yet person A cannot be at the same time and in the same respect at a liberty (i.e., no duty not to) towards person B to charge her for traversing the land and at duty towards person B not to charge her for doing so.

From all this we should therefore conclude that rejection of normative account of freedom and particularly of free exchange, voluntariness, coercion and forcing results in contradiction. It cannot be the case that by exercising their property rights person $A$ forces person $B$ to perform an action and thereby violates person B's rights. Such a scenario is anathema for a theory of natural or moral rights which libertarianism certainly is an instance of. Any theory of natural rights seeks to describe a set of rationally justified rights. However, nothing that is contradictory can be rationally justified. Hence, the answer to the question whether person A forces person B to perform or to forego a given action depends not only on the question whether person A makes other options unappealing to person B but also and crucially on whether person A makes them unappealing 
illegitimately. Suffering from contradiction as it does, Cohen's account of freedom does not therefore seem superior to the allegedly circular yet non-contradictory view of choice, voluntariness and coercion proposed by libertarianism.

\section{CONCLUSIONS}

In the present paper we examined an aspect of a challenge to libertarianism formulated by G.A. Cohen. According to this challenge, libertarianism suffers from circularity in its theory of freedom, since it defines the latter in terms of justice and justice in terms of freedom. Specifically, it seems to Cohen that if person $\mathrm{A}$ is made to do $\varphi$ (e.g., to take another route) by person $\mathrm{B}$, she is forced to do $\varphi$ regardless of the question whether person B's actions are legitimate or not. However, if forcing is understood as an obstacle to a valid transfer of rights - as it has always been since Locke's times - then the question whether person B's actions are legitimate or not appears to be a crucial one. For if person B's actions indeed are legitimate, then it means that person $B$ is at a liberty to perform them. If they nonetheless violated person A's rights by coercing him/her to do $\varphi$, then as far as we talk about a set of compossible rights (see: Steiner, 1977, pp. 767-775), they would be able to do it only by breaching person B's duty not to perform actions which violate other people's rights. Yet as Hohfeldian analysis further shows, person B cannot be at the same time, in the same respect and to the same person at duty not to do one thing and at a liberty to do the very same thing. Liberty-to and duty-not are deontic opposites. Hence, if we wanted to adapt Cohen's idea that person $\mathrm{A}$ is forced to do $\varphi$ by person B regardless of the question whether person B's actions are legitimate or not, we would run into contradiction.

\section{REFERENCES:}

Barnett, R.E. (2004). The Structure of Liberty: Justice and the Rule of Law. New York: Oxford University Press.

Calabresi, G., \& Melamed, A.D. (1972). Property Rules, Liability Rules, and Inalienability Rules: One View of the Cathedral. Harvard Law Review, 85(6), 1089-1128.

Cohen, G.A. (1995). Self-Ownership, Freedom, and Equality. New York: Cambridge University Press. 
Epstein, R.A. (1975). Unconscionability: A Critical Reappraisal. Journal of Law and Economics, 18(2), 293-315.

Epstein, R.A. (1985). Takings: Private Property and the Power of Eminent Domain. Cambridge: Harvard University Press.

Epstein, R.A. (1997). A Clear View of The Cathedral: The Dominance of Property Rules. The Yale Law Journal, 106(7), 2091-2120. DOI: 10.2307/797162.

Hohfeld, W. (1913). Some Fundamental Legal Conceptions as Applied in Judicial Reasoning. The Yale Law Journal, 23(1), 16-59. DOI: 10.2307/785533.

Hohfeld, W. (1917). Fundamental Legal Conceptions as Applied in Judicial Reasoning. The Yale Law Journal, 26(8), 710-770 (cited after: Faculty Scholarship Series, article 4378).

Honoré, A. (1961). Ownership. In: A.G. Guest (ed.), Oxford Essays in Jurisprudence (pp. 107-126). Oxford: Oxford University Press.

Kramer, M.H. (2000). Rights Without Trimmings. In: M.H. Kramer, N.E. Simmonds, \& H. Steiner, A Debate Over Rights: Philosophical Enquiries (pp. 7-112). New York: Oxford University Press.

Nozick, R. (2014). Anarchy, State, and Utopia. Oxford: Blackwell Publishers.

Rothbard, M. (1998). The Ethics of Liberty. New York: New York University Press.

Rothbard, M. (2002). For a New Liberty: The Libertarian Manifesto. New York: Macmillan Publishing.

Steiner, H. (1977). The Structure of a Set of Compossible Rights. Journal of Philosophy, 74(12), 767-775. DOI: $10.2307 / 2025928$.

Steiner, H. (1994). An Essay on Rights. Oxford: Blackwell Publishers. von Wright, G.H. (1951). Deontic Logic. Mind, 60 (237), 1-15. Wertheimer, A. (1989). Coercion. Princeton: Princeton University Press. 